\title{
Enhanced temperature variability in high-altitude climate change
}

\section{Journal Article}

\section{Author(s):}

Ohmura, Atsumu

Publication date:

2012-12

Permanent link:

https://doi.org/10.3929/ethz-b-000060032

Rights / license:

In Copyright - Non-Commercial Use Permitted

Originally published in:

Theoretical and Applied Climatology 110(4), https://doi.org/10.1007/s00704-012-0687-x 


\title{
Enhanced temperature variability in high-altitude climate change
}

\author{
Atsumu Ohmura \\ Received: 10 March 2012 / Accepted: 9 May 2012 /Published online: 27 June 2012 \\ (C) Springer-Verlag 2012
}

\begin{abstract}
In the present article, monthly mean temperature at 56 stations assembled in 18 regional groups in 10 major mountain ranges of the world were investigated. The periods of the analysis covered the last 50 to 110 years. The author found that the variability of temperature in climatic time scale tends to increase with altitude in about $65 \%$ of the regional groups. A smaller number of groups, $20 \%$, showed the fastest change at an intermediate altitude between the peaks (or ridges) and their foot, while the remaining small number of sites, $15 \%$, showed the largest trends at the foot of mountains. This tendency provides a useful base for considering and planning the climate impact evaluations. The reason for the amplification of temperature variation at high altitudes is traced back to the increasing diabatic processes in the midand high troposphere as a result of the cloud condensation. This situation results from the fact that the radiation balance at the earth's surface is transformed more efficiently into latent heat of evaporation rather than sensible heat, the ratio between them being 4 to 1 . Variation in the surface evaporation is converted into heat upon condensation into cloud particles and ice crystals in the mid- and high troposphere. Therefore, this is the altitude where the result of the surface radiation change is effectively transferred. Further, the low temperature of the environment amplifies the effect of the energy balance variation on the surface temperature, as a result of the functional shape of Stefan-Boltzmann law. These processes altogether contribute to enhancing temperature variability at high altitudes. The altitude plays an important role in determining the temperature variability, besides other important factors such as topography, surface characteristics, cryosphere/temperature feedback and the frequency and intensity of an
\end{abstract}

\footnotetext{
A. Ohmura $(\triangle)$

Institute for Atmospheric and Climate Science,

Swiss Federal Institute of Technology (E.T.H.),

Universitätsstrasse 16,

Zuerich, Switzerland

e-mail: ohmura@env.ethz.ch
}

inversion. These processes have a profound effect not only on the ecosystem but also on glaciers and permafrost.

\section{Introduction}

From ecological observations it has been known that the ecosystem is more vulnerable to external changes at high altitudes than on low lands (Messerli and Ives 1997). The flora at high altitudes is made of sensitive species and its composition is highly selected. Therefore, the vulnerability of the high-altitude ecosystem is usually attributed to the sensitivity of the high-altitude biosphere. This is only partially correct. There is another factor that promotes the ecosystem vulnerability with increasing altitude. The amplitude of climate variability may be more pronounced with increasing altitude (Barry 1992). Important climatic elements are temperature and precipitation. The present work aims at analysing the altitude dependency of surface air temperature in a climatic time scale in the major mountain areas of the world. Further, possible causes, resulting in the altitude dependency will be considered.

The altitude dependency of climatic temperature change has long been an object of interest from both theoretical and applicational viewpoints. One of the most comprehensive surveys in this subject was done by Diaz and Bradley (1997), based on the surface observations from 113 stations grouped in 12 regions collected from major mountainous regions of the Northern Hemisphere. The stations ranged in altitude from 329 to $4,169 \mathrm{~m}$ above sea level (a.s.l.). The periods covered in their work range from more than a century to about 30 years. They report the increasing rate of warming with altitude, which is propelled by the faster increase in daily minimum temperature rather than the maximum. Beniston et al. (1997) also found that the rate of warming at stations in the Swiss Alps during the twentieth century was larger than the global mean evaluated by Jones and Wigley (1990). There are contradicting conclusions 
(e.g. Pepin 2000), however, reporting a decreasing rates of temperature change with increasing altitude. A similar conclusion was drawn by Vuille and Bradley (2000) for the Pacific side of the Andes.

The progress in this subject has often been hampered by the lack of long-term homogenous observations at high altitudes. Some studies tried to circumvent this problem by incorporating the data in the free atmosphere, which were measured by radiosondes (Seidel and Free 2003; Sterin et al. 2008) or satellite-based remote sensing estimations (Lanzante et al. 2006) or Reanaluses (Pepin and Seidel 2005). The results of current studies are, however, inconclusive. The Third Assessment Report of Intergovernmental Panel on Climate Change (IPCC) stated that the temperature change at the surface was larger than in the lower troposphere, while the IPCC Forth Assessment Report concluded the opposite (Trenberth et al. 2007). Both reports indicated certain reservations on the conclusion due to the large error range of radiosondes and satellite remote sensing methods. The basic problem in these works was the incompatibility between the data obtained at the conventional surface meteorological stations and those obtained by radiosondes and satellite sensors, or even reanalyses. The data incompatibility includes the basic difference between the earth's surface temperature and that of the free atmosphere, the different instrumental uncertainties and the differences in sampling time and space, in addition to the known problem of the data inhomogeneity of reanalysis fields. Further, the altitude dependency may be different depending on regions. In the present article, only the temperature series obtained at surface meteorological stations are used. The stations are in a pair or a group closely located in horizontal distance but separated by large altitude differences. In total, 18 groups of stations are selected from 10 mountain regions of the world. Each group consisted of two to six stations, whereby at least one station occupies the highest location in the region and the other(s) are located at lower altitudes. In total, the observational series from 56 stations are investigated. This type of analysis helps exclude the abovementioned data incompatibility problem and contributes to extracting more genuinely the influence of altitudes on climate changes.

\section{Data}

The author searched globally for the availability of the air temperature observations for periods longer than 50 years at least at two locations in a pair within a short horizontal distance but separated by more than $800 \mathrm{~m}$ in altitude. The sources of the data are monthly mean air temperature stored in (1) Global Historical Climate Network Version 3 (Peterson and Vose 1997); (2) Climate Research Unit, University of East Anglia Temperature Station Data; and (3) on- and off-line supply of meteorological data from national meteorological services of the nations covered in the present work. The data from source 3 from meteorological services were especially important to replace doubtful entries in the first two databases and also to supplement the data of the most recent years. In the course of selecting stations, the sites with growing urban effect were avoided. To clarify the urban effect and the relocation history of the site, the author requested and received station meta-data from meteorological services of the relevant countries. The author visited 28 stations personally to evaluate the suitability of the sites and visually to reconstruct the history of the observation circumstances. If there were more than two stations within the area, additional stations were also taken into account, especially to fill the gap between the highest and lowest stations. For the present analysis, the data before 1901 were not used, except for the Austrian Alps, as the quality of homogeneity of older data for many stations was not the same as those of the subsequent years. The minimum length of the time series was set at 50 years. However, when slightly shorter data of high quality were available in the neighbourhood of the mountain stations, they were used only for the analysis of the current warming stage. The stations in the 18 groups from 10 regions presented in Table 1 fulfilled these conditions. Nevertheless, the quality of the time series may vary among the stations. Many stations, such as Sonnblick, Srinagar, New Delhi, Daxigou, Hushiki, Temuco, Calgary International Airport and Mt. Washington are full-scale synoptic meteorological stations manned by experienced observers, with other auxiliary observations such as radiation and evaporation measurements. Stations, such as Säntis and Fujisan had been full-scale synoptic meteorological stations until sometime in the past, when manned observations were replaced by automatic observation systems. The other stations, such as St. Gallen, Badgastein and Pinkham Notch are smaller stations with basic climatological observations carried out daily at fixed hours that are less frequent than the eight times required for the main synoptic observations. All these stations have the air temperature measurement as one of the main observations, and a considerable amount of work has been carried out to homogenize the data (e.g. Auer, et al. 2007; Böhm et al. 2009; MeteoSwiss 2010).

\section{The data analysis}

The linear trend was calculated for the entire periods for which usable data exist at all stations in each group. The periods with usable data are determined by eliminating the data with frequently missing observations, or with serious relocations of the sites from the existing data series. The period finally adopted must also have simultaneous coverage for all stations in the group. The period of usable data contains for most regions three phases of temperature change: the initial warming phase during the early twentieth century, followed by the 
stagnating or even cooling phase starting between 1940 and 1960 , which ended by 1970s to 1980 s, followed by the present warming phase. The actual periods for these phases are different for the regions and also the groups. The trend analysis was made for each of the three periods for each station, that is, for the entire period of the used data, for the mid-

Table 1 Decadal trends of annual and seasonal mean temperature for 10 major mountain regions of the world: trends are presented for the entire perios of the data availability, the mid-century cooling (or stagnating) period, and for the recent warming phase of the last 30 to 40 years

\begin{tabular}{|c|c|c|c|c|c|c|c|c|c|c|c|c|c|c|c|c|c|c|c|c|c|}
\hline Swiss Alps & & & & & & & & Trend & for & neriod & & & Trenc & f for 1933 & & & & Tren & f for 1970 & -2011 & \\
\hline & WMO ID & Latitude & Longitude & $\begin{array}{l}\text { Altitude } \\
\text { m a.s.l. }\end{array}$ & Available data & Usable period & spring & $\begin{array}{l}\text { Trend } \\
\text { summer }\end{array}$ & autumn & $\begin{array}{l}\text { period } \\
\text { winter }\end{array}$ & annual & spring & $\begin{array}{r}\text { Tren } \\
\text { summer }\end{array}$ & $\begin{array}{l}\text { de for } 1935 \\
\text { autumn }\end{array}$ & winter & annual & spring & $\begin{array}{l}\text { Tren } \\
\text { summmer }\end{array}$ & $\begin{array}{l}\text { d for } 1970 \\
\text { autumn }\end{array}$ & $\begin{array}{l}-2011 \\
\text { winter }\end{array}$ & annual \\
\hline Jungfraujoch & 6730 & $46^{\circ} 33^{\prime} \mathrm{N}$ & $7^{\circ} 59^{\prime} \mathrm{E}$ & 3580 & 1933-2011 & 1933-2011 & 0.09 & 0.13 & 0.11 & 0.25 & 0.14 & -0.32 & -0.34 & 0.27 & -0.15 & -0.13 & 0.67 & 0.57 & 0.36 & 0.15 & 0.43 \\
\hline Interlaken & 6734 & $46^{\circ} 67 \mathrm{~N}$ & $7^{\circ} 87^{\prime} \mathrm{W}$ & 577 & 1931-2011 & 1933-2011 & 0.10 & 0.12 & 0.04 & 0.08 & 0.09 & -0.13 & -0.10 & -0.03 & -0.14 & -0.10 & 0.56 & 0.51 & 0.37 & 0.02 & 0.36 \\
\hline & & & & & & & & & & & & & Trend fo & for $1901-19$ & & & & Tren & $d$ for 1971 & -2011 & \\
\hline Säntis & 6680 & $47^{\circ} 15 \mathrm{~N}$ & $9^{\circ} 20^{\prime} \mathrm{E}$ & 2502 & 1864-2011 & 1901-2011 & 0.11 & 0.18 & 0.20 & 0.14 & 0.16 & 0.11 & 0.12 & 0.27 & -0.09 & 0.11 & 0.65 & 0.70 & 0.45 & 0.12 & 0.47 \\
\hline Mean of 3 lower sites & & & & 618 & & 1971-2011 & & & & & & & & & & & 0.47 & 0.34 & 0.28 & 0.17 & 0.32 \\
\hline St. Gallen & 6681 & $47^{\circ} 26^{\prime} \mathrm{N}$ & $9^{\circ} 24^{\prime} \mathrm{E}$ & 776 & 1864-2011 & 1901-2011 & 0.11 & 0.13 & 0.15 & 0.15 & 0.14 & 0.06 & 0.09 & 0.20 & -0.02 & 0.08 & 0.43 & 0.34 & 0.27 & 0.13 & 0.29 \\
\hline Ebnat-Kappel & 6693 & $47^{\circ} 16 \mathrm{~N}$ & $9^{\circ} 07 \mathrm{E}$ & 620 & 1959-2011 & 1971-2011 & & & & & & & & & & & 0.46 & 0.34 & 0.24 & 0.12 & 0.29 \\
\hline Vaduz & 6990 & $47^{\circ} 08 \mathrm{~N}$ & $9^{\circ} 31^{\mathrm{E}} \mathrm{E}$ & 457 & 1971-2011 & 1971-2011 & & & & & & & & & & & 0.52 & 0.34 & 0.34 & 0.27 & 0.37 \\
\hline Austrian Alps & & & & & & & & & & & & & & & & & & & & & \\
\hline Station & WMO ID & Latitude & Longitude & Altitude & Available data & Usable period & & Trend & for entire & period & & & Tren & de for 1950 & 1980 & & & Tren & d for 198 & -2011 & \\
\hline & & & & m a.s.l. & & & spring & summer & autumn & winter & annual & spring & summer & autumn & winter & annual & spring & summer & autumn & winter & annual \\
\hline Sonnblick & 11146 & $47^{\circ} 03^{\prime} \mathrm{N}$ & $12^{\circ} 57^{\prime} \mathrm{E}$ & 3109 & $1887-2010$ & $1887-2010$ & 0.14 & 0.17 & 0.12 & 0.12 & 0.14 & 0.08 & 0.09 & 0.14 & 0.07 & 0.10 & 0.60 & 0.46 & -0.08 & 0.22 & 0.30 \\
\hline Badgastein & 11372 & $47^{\circ} 07^{\prime} \mathrm{N}$ & $13^{\circ} 08^{\prime} \mathrm{E}$ & 1100 & $1854-2010$ & $1887-2010$ & 0.12 & 0.13 & 0.12 & 0.14 & 0.13 & 0.07 & 0.05 & 0.13 & 0.12 & 0.09 & 0.43 & 0.39 & 0.06 & 0.14 & 0.24 \\
\hline India and Pakistan & & & & & & & & & & & & & & & & & & & & & \\
\hline Station & WMO ID & Latitude & Longitude & Altitude & Available data & Usable period & & Trend & for entire & period & & & Tren & d for 1949 & 1980 & & & Tren & d for 1980 & -2010 & \\
\hline & & & & m a.s.1. & & & spring & summer & autumn & winter & annual & spring & summer & autumn & winter & annual & spring & summer & autumn & winter & annual \\
\hline Srinagar & 42027 & $34^{\circ} 05^{\prime} \mathrm{N}$ & $74^{\circ} 50^{\prime} \mathrm{E}$ & 1583 & $1893-2010$ & $1949-2010$ & 0.32 & 0.01 & 0.09 & 0.36 & 0.20 & 0.28 & 0.15 & 0.11 & 0.16 & 0.16 & $0.60^{\circ}$ & 0.08 & 0.24 & 0.44 & 0.32 \\
\hline Peshawar & 41530 & $34^{\circ} 01^{\prime} \mathrm{N}$ & $71^{\circ} 35^{\prime} \mathrm{E}$ & 359 & 1931-2010 & 1949-2010 & 0.15 & -0.07 & 0.02 & 0.13 & 0.13 & 0.10 & -0.08 & 0.16 & 0.13 & 0.10 & 0.86 & -0.07 & 0.09 & 0.26 & 0.28 \\
\hline & & & & & & & & & & & & & Trenc & d for 1931 & 1980 & & & & & & \\
\hline Mukteshwar & 42147 & $29^{\circ} 28^{\mathrm{N}} \mathrm{N}$ & $79^{\circ} 39^{\prime} \mathrm{E}$ & 2311 & $1898-2010$ & $1931-2010$ & 0.09 & 0.08 & 0.19 & 0.27 & 0.11 & 0.13 & -0.05 & 0.07 & 0.22 & 0.10 & 0.55 & 0.40 & 0.58 & 0.58 & 0.48 \\
\hline New Delhi & 42182 & $28^{\circ} 35^{\prime} \mathrm{N}$ & $77^{\circ} 12^{\prime} \mathrm{E}$ & 216 & $1931-2010$ & $1931-2010$ & 0.02 & 0.01 & 0.08 & 0.06 & 0.04 & 0.00 & -0.12 & 0.14 & 0.05 & 0.02 & 0.49 & 0.08 & 0.01 & 0.06 & 0.16 \\
\hline Mo & & & & & & & & & & & & & & & & & & & & & \\
\hline Station & WMO ID & Latitude & Longitude & Altitude & Available data & Usable period & & Trend & for entire & period & & & Tren & d for 1940 & -1970 & & & Tren & d for 1970 & -2010 & \\
\hline & & & & m a.s.l. & & & spring & summer & autumn & winter & annual & spring & summer & autumn & winter & annual & spring & summer & autumn & winter & annual \\
\hline Arvaiheer & 44288 & $46^{\circ} 16^{\prime} \mathrm{N}$ & $102^{\circ} 47^{\mathrm{E}} \mathrm{E}$ & 1813 & $1940-2010$ & $1940-2010$ & 0.28 & 0.25 & 0.31 & 0.42 & 0.31 & -0.09 & -0.19 & -0.09 & 0.05 & -0.09 & 0.52 & 0.72 & 0.42 & 0.18 & 0.55 \\
\hline Choibalsan & 44259 & $48^{\circ} 05^{\top} \mathrm{N}$ & $114^{\circ} 33^{\mathrm{E}} \mathrm{E}$ & 747 & $1937-2010$ & $1940-2010$ & 0.38 & 0.08 & 0.16 & 0.45 & 0.26 & -0.06 & -0.40 & -0.30 & 0.16 & -0.13 & 0.67 & 0.53 & 0.26 & 0.21 & 0.37 \\
\hline $\mathrm{Ch}$ & & & & & & & & & & & & & & & & & & & & & \\
\hline Station & WMO ID & Latitude & Longitude & Altitude & Available data & Usable period & & Trend & for entire & period & & & Tren & d for 1959 & 1970 & & & Tren & d for 1970 & -2005 & \\
\hline & & & & $m$ a.s.1. & & & spring & summer & autumn & winter & annual & spring & summer & autumn & winter & annual & spring & summer & autumn & winter & annual \\
\hline Daxigou & $51468^{*}$ & $43^{\circ} 06^{\prime} \mathrm{N}$ & $86^{\circ} 50^{\prime} \mathrm{E}$ & 3539 & 1959-2010 & $1959-2010$ & 0.13 & 0.21 & 0.34 & 0.27 & 0.24 & 0.60 & 0.23 & -0.63 & -0.97 & -0.24 & 0.25 & 0.31 & 0.31 & 0.45 & 0.32 \\
\hline Hami & 51495 & $42^{\circ} 49^{\prime} \mathrm{N}$ & $93^{\circ} 31^{\prime} \mathrm{E}$ & 739 & $1953-2010$ & $1959-2010$ & 0.66 & 0.13 & 0.14 & 0.34 & 0.09 & 0.11 & -0.30 & -0.35 & -1.49 & -0.41 & 0.97 & 0.19 & 0.13 & 0.33 & 0.05 \\
\hline & & & & & & & & & & & & & Trens & $\mathrm{d}$ for 1953 & 1970 & & & Tren & d for 1970 & -2005 & \\
\hline Jiuquan & 52533 & $39^{\circ} 46^{\mathrm{N}} \mathrm{N}$ & $98^{\circ} 29^{\prime} \mathrm{E}$ & 1478 & $1935-2010$ & $1953-2010$ & 0.19 & 0.10 & 0.17 & 0.32 & 0.21 & -0.26 & -1.23 & -0.84 & -0.93 & -0.61 & 0.43 & 0.45 & 0.22 & 0.40 & 0.36 \\
\hline Minqin & 52681 & $38^{\circ} 38 \mathrm{~N}$ & $103^{\circ} 05^{\prime} \mathrm{E}$ & 1369 & $1953-2010$ & $1953-2010$ & 0.26 & 0.16 & 0.19 & 0.23 & 0.21 & -0.01 & -0.34 & -0.36 & -0.74 & -0.30 & 0.44 & 0.22 & 0.25 & 0.46 & 0.35 \\
\hline Ruoqiang & 51777 & $39^{\circ} 02^{\prime} \mathrm{N}$ & $88^{\circ} 10^{\prime} \mathrm{E}$ & 889 & 1953-2010 & $1953-2010$ & 0.17 & 0.09 & 0.10 & 0.36 & 0.18 & -0.15 & -0.81 & -0.38 & 0.19 & -0.24 & 0.31 & 0.38 & 0.20 & 0.40 & 0.32 \\
\hline & & & & & & & & & & & & & Tren & d for 1961 & 1970 & & & Tren & dfor 1970 & 2005 & \\
\hline Toutouhe & 56004 & $34^{\circ} 13 \mathrm{~N}$ & $92^{\circ} 31^{\prime} \mathrm{E}$ & 4535 & $1958-2010$ & $1961-2010$ & 0.17 & 0.07 & 0.17 & 0.30 & 0.17 & 0.89 & -0.59 & -1.68 & 1.16 & 0.11 & -0.05 & 0.05 & -0.01 & 0.18 & 0.02 \\
\hline Dariag & 56046 & $33^{\circ} 45^{\prime} \mathrm{N}$ & $99^{\circ} 39^{\prime} \mathrm{E}$ & 3968 & 1956-2010 & $1961-2010$ & 0.11 & 0.20 & 0.10 & 0.48 & 0.22 & 0.54 & -0.66 & -0.66 & 0.90 & 0.14 & 0.10 & 0.30 & 0.07 & 0.75 & 0.25 \\
\hline Yushu & 56029 & $33^{\circ} 01 \mathrm{~N}$ & $97^{\circ} 02^{\prime} \mathrm{E}$ & 3682 & $1954-2010$ & $1961-2010$ & 0.11 & 0.17 & 0.07 & 0.37 & 0.18 & 0.83 & -0.02 & -0.37 & 1.14 & 0.50 & -0.04 & 0.14 & -0.08 & 0.31 & 0.07 \\
\hline Ruoergai & 56079 & $33^{\circ} 35 \mathrm{~N}$ & $102^{\circ} 58^{\mathrm{E}} \mathrm{E}$ & 3441 & $1959-2010$ & 1961-2010 & -0.07 & 0.17 & 0.00 & 0.34 & 0.11 & 0.60 & -0.49 & -1.38 & 0.78 & -0.05 & -0.23 & 0.32 & 0.17 & 0.56 & 0.23 \\
\hline Hanzhong & 57127 & $33^{\circ} 04^{1} \mathrm{~N}$ & $107^{\circ} 02^{2} \mathrm{E}$ & 509 & $1936-2010$ & $1961-2010$ & 0.16 & -0.10 & 0.05 & 0.07 & 0.05 & -0.36 & 0.06 & -0.65 & -0.76 & -0.44 & 0.26 & 0.02 & 0.07 & 0.10 & 0.12 \\
\hline Japan & & & & & & & & & & & & & & & & & & & & & \\
\hline Station & WMO ID & Latitude & Longitude & Altitude & Available data & Used period & & Trend & for entire & period & & & Trenc & d for 1940 & 1985 & & & Tren & d for 198 & -2005 & \\
\hline & & & & m a.s.l. & & & spring & summer & autumn & winter & annual & spring & summer & autumn & winter & annual & spring & summer & autumn & winter & annual \\
\hline Fujisan & 47639 & $35^{\circ} 22 \mathrm{~N}$ & $138^{\circ} 44^{\prime} \mathrm{E}$ & 3775 & 1933-2011 & 1940-2011 & 0.11 & 0.09 & 0.13 & 0.20 & 0.13 & 0.18 & -0.03 & -0.12 & 0.04 & 0.001 & 0.35 & 0.39 & 0.77 & 0.21 & 0.35 \\
\hline Honshu Reference mean & & & & 11 & $1893-2011$ & $1940-2011$ & 0.21 & 0.10 & 0.17 & 0.18 & 0.17 & 0.18 & 0.08 & 0.06 & 0.05 & 0.09 & 0.60 & 0.47 & 0.45 & 0.29 & 0.44 \\
\hline Yamanaka & $49256^{*}$ & $35^{\circ} 26^{\prime} \mathrm{N}$ & $138^{\circ} 50^{\prime} \mathrm{E}$ & 992 & 1977-2011 & $1985-2011$ & & & & & & & & & & & 0.37 & 0.50 & 0.24 & 0.06 & 0.24 \\
\hline Kawaguchiko & 47640 & $35^{\circ} 30 \mathrm{~N}$ & $138^{\circ} 46^{\prime} \mathrm{E}$ & 860 & 1933-2011 & 1940-2011 & 0.23 & 0.18 & 0.20 & 0.24 & 0.21 & 0.23 & 0.06 & 0.03 & 0.15 & 0.11 & 0.65 & 0.71 & 0.51 & 0.26 & 0.51 \\
\hline Shizuoka & 47656 & $34^{\circ} 59 \mathrm{~N}$ & $138^{\circ} 24^{\prime} \mathrm{E}$ & 14 & 1940-2011 & 1940-2011 & 0.24 & 0.16 & 0.23 & 0.26 & 0.22 & 0.27 & 0.10 & 0.14 & 0.18 & 0.18 & 0.48 & 0.49 & 0.39 & 0.22 & 0.36 \\
\hline The & & & & & & & & & & & & & & & & & & & & & \\
\hline Station & WMO ID & Latitude & Longitude & Altitude & Available data & Usable period & & Trend & for entire & period & & & Trenc & d for 1963 & 1970 & & & Tren & d for 1970 & -2010 & \\
\hline & & & & $m$ a.s.l. & & & spring & summer & autumn & winter & annual & spring & summer & autumn & winter & annual & spring & summer & autumn & winter & annual \\
\hline Bariloche Aer & 87765 & $41^{\circ} 09^{\prime} \mathrm{S}$ & $71^{\circ} 10^{\prime} \mathrm{W}$ & 840 & $1931-2010$ & $1963-2010$ & 0.19 & 0.42 & 0.06 & 0.08 & 0.19 & 1.43 & -0.23 & 0.64 & -0.28 & 0.41 & 0.10 & 0.38 & 0.02 & 0.08 & 0.15 \\
\hline Temuco & 85743 & $38^{\circ} 45^{\prime} \mathrm{S}$ & $72^{\circ} 38^{\prime} \mathrm{W}$ & 114 & $1951-2010$ & $1963-2010$ & 0.04 & 0.13 & -0.03 & 0.07 & 0.05 & 0 & -1.27 & -1.02 & -0.71 & -0.95 & -0.02 & 0.10 & -0.02 & 0.09 & 0.04 \\
\hline Puerto Montt & 85799 & $41^{\circ} 25^{\prime} \mathrm{S}$ & $73^{\circ} 05^{\prime} \mathrm{W}$ & 85 & $1951-2010$ & $1963-2010$ & 0.01 & 0.10 & 0.03 & -0.03 & 0.00 & 0.45 & 0.85 & 1.27 & 0.94 & 0.92 & 0.02 & 0.14 & 0.02 & 0.02 & 0.04 \\
\hline & & & & & & & & & & & & & Tren & d for 195 & 1970 & & & Tren & d for 1970 & -2010 & \\
\hline La Quiaca & 87007 & $22^{\circ} 06^{\prime} \mathrm{S}$ & $65^{\circ} 36^{\prime} \mathrm{W}$ & 3459 & $1951-2010$ & $1951-2010$ & 0.25 & 0.17 & 0.15 & 0.11 & 0.15 & 0.39 & 0.15 & 0.08 & -0.04 & 0.16 & 0.52 & 0.40 & 0.24 & 0.20 & 0.32 \\
\hline Antofagasta & 85442 & $23^{\circ} 26^{\prime \prime S}$ & $70^{\circ} 26^{\prime} \mathrm{W}$ & 135 & 1911-2010 & $1951-2010$ & 0.05 & 0.02 & 0.03 & 0.04 & 0.03 & 0.06 & -0.08 & -0.18 & 0.07 & -0.06 & 0.12 & 0.08 & 0.10 & 0.07 & 0.09 \\
\hline & & & & & & & & & & & & & Tre & d for 1943 & 1985 & & & & d for 1985 & -2010 & \\
\hline La Paz & 85201 & $16^{\circ} 31 \mathrm{~S}$ & $68^{\circ} 11^{\prime} \mathrm{W}$ & 4038 & $1918-2010$ & 1943-2010 & 0.10 & 0.17 & -0.01 & -0.1 & 0.08 & 0.28 & 0.25 & 0. & 0.06 & 0.18 & -0.62 & -0.15 & -0.63 & -1.63 & -0.70 \\
\hline $\mathrm{Cuz}$ & 846 & 3033'S & $71^{\circ} 59^{\prime} \mathrm{W}$ & 32 & & & 0. & 0.25 & 0. & 0. & 0.20 & 0.13 & 0.2 & 0. & 0 . & 0.23 & 0.29 & -0.13 & -0.11 & 0.19 & 0.00 \\
\hline Cochabamba & 85223 & $17^{\circ} 25^{\prime} \mathrm{S}$ & $66^{\circ} 11^{\prime} \mathrm{W}$ & 2548 & $1941-2010$ & $1943-2010$ & 0.02 & -0.02 & -0.03 & 0.04 & 0.04 & 0.32 & 0.03 & -0.03 & 0.08 & 0.09 & -0.69 & -0.34 & -0.51 & -0.55 & -0.47 \\
\hline Santa Cruz & 85245 & $17^{\circ} 48^{\prime S}$ & $63^{\circ} 11 \mathrm{~W}$ & 418 & 1943-2010 & 1943-2010 & 0.12 & 0.12 & 0.17 & 0.01 & 0.10 & 0.08 & 0.19 & 0.23 & -0.19 & 0.08 & -0.25 & -0.44 & -0.26 & -0.16 & -0.30 \\
\hline & & & & & & & & & & & & & & 101190 & & & & & for 1980 & 2010 & \\
\hline Bogota & 80222 & $4^{\circ} 43^{\prime} \mathrm{N}$ & $74^{\circ} 09^{\prime} \mathrm{W}$ & 2548 & $1959-2010$ & $1961-2010$ & 0.21 & 0.28 & 0.23 & 0.27 & 0.26 & 0.42 & 0.45 & 0.51 & 0.30 & 0.44 & 0.05 & 0.11 & 0.08 & 0.12 & 0.09 \\
\hline Calipuerto & 80259 & $3^{\circ} 24 \mathrm{~N}$ & $76^{\circ} 24^{\prime} \mathrm{W}$ & 964 & 1951-2010 & $1961-2010$ & 0.24 & 0.22 & 0.23 & 0.22 & 0.23 & 0.51 & 0.32 & 0.31 & 0.23 & 0.35 & 0.11 & 0.10 & 0.14 & 0.19 & 0.13 \\
\hline Villavicencio & 80234 & $4^{\circ} 10^{\prime} \mathrm{N}$ & $73^{\circ} 37^{\prime} \mathrm{W}$ & 431 & $1961-2010$ & $1961-2010$ & 0.21 & 0.27 & 0.27 & 0.26 & 0.24 & 0.15 & 0.25 & 0.10 & 0.29 & 0.14 & 0.30 & 0.38 & 0.20 & 0.30 & 0.26 \\
\hline $\begin{array}{l}\text { North America } \\
\text { Cordillera }\end{array}$ & & & & & & & & & & & & & & & & & & & & & \\
\hline Station & WMO ID & Latitude & Longitude & Altitude & Available data & Usable period & & Trend & for ent & eriod & & & Trens & $\mathrm{d}$ for 19 & & & & & & 005 & \\
\hline & & & & m a.s.1 & & & spring & summer & autumn & winter & annual & spring & summer & autumn & winter & annual & spring & summer & autumn & winter & annual \\
\hline Fly & $72486-0$ & $39^{\circ} 17^{\prime} \mathrm{N}$ & $114^{\circ} 51^{\prime} \mathrm{W}$ & 1909 & $1948-2010$ & $1949-2010$ & 0.25 & 0.17 & -0.04 & 0.16 & 0.16 & -0.05 & 0.20 & -0.27 & 1.25 & 0.22 & 0.48 & 0.21 & 0.26 & 0.13 & 0.29 \\
\hline Grand Junction & $72476-0$ & $39^{\circ} 07^{\prime} \mathrm{N}$ & $108^{\circ} 32^{\prime} \mathrm{W}$ & 1475 & $1892-2010$ & $1949-2010$ & 0.23 & 0.16 & -0.04 & 0.17 & 0.13 & 0.15 & 0.35 & -0.13 & 0.28 & 0.18 & 0.49 & 0.04 & 0.08 & 0.69 & 0.33 \\
\hline Salt Lake City & $72572-0$ & $40^{\circ} 47 \mathrm{~N}$ & $111^{\circ} 58^{\circ} \mathrm{W}$ & 1288 & $1875-2010$ & $1949-2010$ & 0.20 & 0.24 & 0.03 & 0.07 & 0.13 & 0.01 & 0.33 & -0.22 & 0.56 & 0.14 & 0.40 & 0.24 & 0.16 & 0.10 & 0.23 \\
\hline Stockton & $72492-0$ & $37^{\circ} 54^{\prime} \mathrm{N}$ & $121^{\circ} 15^{\prime} \mathrm{W}$ & 8 & $1949-2010$ & $1949-2010$ & 0.20 & 0.08 & 0.06 & -0.10 & 0.14 & -0.81 & 0.45 & -0.28 & -1.31 & -0.37 & 0.40 & 0.07 & 0.29 & -0.09 & 0.18 \\
\hline
\end{tabular}


Table 1 (continued)

\begin{tabular}{|c|c|c|c|c|c|c|c|c|c|c|c|c|c|c|c|c|c|c|c|c|c|}
\hline \multirow[b]{2}{*}{ Banff } & \multirow[b]{2}{*}{$71122-0$} & \multirow[b]{2}{*}{$51^{\circ} 11^{\prime} \mathrm{N}$} & \multirow[b]{2}{*}{$115^{\circ} 34^{\prime} \mathrm{W}$} & \multirow[b]{2}{*}{1,384} & \multirow[b]{2}{*}{ 1890-2010 } & \multirow[b]{2}{*}{$1910-2010$} & \multirow[b]{2}{*}{0.07} & \multirow[b]{2}{*}{0.04} & \multirow[b]{2}{*}{0.02} & \multirow[b]{2}{*}{0.22} & \multirow[b]{2}{*}{0.09} & \multicolumn{5}{|c|}{ Trend $1910-1970$} & \multicolumn{5}{|c|}{ Trend for 1970-2005 } \\
\hline & & & & & & & & & & & & -0.06 & 0.06 & 0.09 & 0.25 & 0.08 & 0.17 & -0.25 & -0.09 & 0.59 & 0.02 \\
\hline High River & $71877-1$ & $50^{\circ} 29^{\prime} \mathrm{N}$ & $114^{\circ} 10^{\prime} \mathrm{W}$ & 1,219 & $1907-2005$ & $1907-2005$ & 0.10 & 0.00 & 0.05 & 0.28 & 0.11 & -0.24 & -0.06 & 0.10 & -0.03 & -0.06 & 0.17 & -0.01 & 0.45 & 0.96 & 0.41 \\
\hline Calgary Intern. A & $71877-0$ & $51^{\circ} 07^{\prime} \mathrm{N}$ & $114^{\circ} 01^{\prime} \mathrm{W}$ & 1,084 & $1885-2010$ & $1910-2010$ & 0.14 & 0.10 & 0.09 & 0.32 & 0.16 & -0.19 & 0.06 & 0.09 & 0.00 & -0.02 & 0.18 & -0.01 & 0.45 & 0.89 & 0.40 \\
\hline \multirow[t]{2}{*}{ Gleichen } & $71877-2$ & $50^{\circ} 53^{\prime} \mathrm{N}$ & $113^{\circ} 03^{\prime} \mathrm{W}$ & 905 & 1904-2010 & 1910-2010 & 0.07 & -0.07 & 0.04 & 0.28 & 0.09 & -0.08 & 0.04 & 0.09 & 0.07 & 0.03 & \multirow{2}{*}{\multicolumn{5}{|c|}{ Trend for $1970-2005$}} \\
\hline & & & & & & & & & & & & \multicolumn{5}{|c|}{ Trend for $1914-1970$} & & & & & \\
\hline Glacier NP Mt. Fidelity & $117 \mathrm{CA} 90$ & $51^{\circ} 14^{\prime} \mathrm{N}$ & $117^{\circ} 42^{\prime} \mathrm{W}$ & 1,890 & $1966-2010$ & $1970-2005$ & & & & & & & & & & & 0.30 & 0.17 & 0.27 & 0.47 & 0.29 \\
\hline Glacier NP Rogers Pass & $71882-5$ & $51^{\circ} 18^{\prime} \mathrm{N}$ & $117^{\circ} 31^{\prime} \mathrm{W}$ & 1,323 & 1966-2007 & $1970-2005$ & & & & & & & & & & & 0.30 & 0.19 & 0.40 & 0.60 & 0.37 \\
\hline Fernie & $71880-3$ & $49^{\circ} 29^{\prime} \mathrm{N}$ & $115^{\circ} 04^{\prime} \mathrm{W}$ & 1,001 & 1913-2010 & 1914-2010 & 0.11 & 0.04 & 0.11 & 0.31 & 0.14 & -0.07 & -0.03 & 0.18 & 0.40 & 0.12 & 0.36 & 0.24 & 0.47 & 0.51 & 0.39 \\
\hline Cranbrook A & 71880 & $49^{\circ} 37^{\prime} \mathrm{N}$ & $115^{\circ} 47^{\prime} \mathrm{W}$ & 940 & $1902-2010$ & $1910-2010$ & 0.09 & 0.10 & 0.09 & 0.25 & 0.14 & -0.13 & -0.01 & 0.11 & 0.23 & 0.06 & 0.28 & 0.11 & 0.35 & 0.56 & 0.33 \\
\hline Revelstoke & $71882-0$ & $51^{\circ} 00^{\prime} \mathrm{N}$ & $118^{\circ} 12^{\prime} \mathrm{W}$ & 456 & 1898-2010 & 1910-2010 & 0.08 & 0.11 & 0.09 & 0.23 & 0.13 & 0.10 & 0.28 & 0.16 & 0.32 & 0.20 & 0.45 & 0.32 & 0.45 & 0.90 & 0.54 \\
\hline Penticton A & 71889 & $49^{\circ} 29^{\prime} \mathrm{N}$ & $119^{\circ} 35^{\prime} \mathrm{W}$ & 344 & 1907-2010 & 1910-2010 & 0.05 & 0.12 & 0.03 & 0.17 & 0.09 & -0.12 & -0.03 & -0.03 & 0.20 & 0.00 & 0.35 & 0.26 & 0.29 & 0.54 & 0.36 \\
\hline \multicolumn{22}{|l|}{ Appalachians } \\
\hline \multirow[t]{2}{*}{ Station } & WMO ID & Latitude & Longitude & Altitude & Available data & Usable period & \multicolumn{5}{|c|}{ Trend for entire period } & \multicolumn{5}{|c|}{ Trend for $1948-1970$} & \multicolumn{5}{|c|}{ Trend for $1970-2005$} \\
\hline & & & & $m$ a.s.l. & & & spring & summer & autumn & winter & annual & spring & summer & autumn & winter & annual & spring & summer & autumn & winter & annual \\
\hline Mt. Washington & $72613-1$ & $44^{\circ} 16^{\mathrm{N}}$ & $71^{\circ} 18^{\prime} \mathrm{W}$ & 1905 & 1937-2010 & 1948-2010 & 0.22 & 0.09 & 0.06 & 0.07 & 0.11 & -0.29 & -0.20 & -0.02 & -1.05 & -0.43 & 0.13 & 0.48 & 0.49 & 0.28 & 0.35 \\
\hline Pinkham Notch & 276818 & $44^{\circ} 16^{\mathrm{N}}$ & $71^{\circ} 15^{\prime} \mathrm{W}$ & 613 & 1948-2010 & $1948-2010$ & 0.05 & 0.06 & 0.03 & -0.02 & 0.04 & -0.50 & -0.37 & -0.46 & -1.76 & -0.69 & 0.15 & 0.31 & 0.45 & 0.32 & 0.31 \\
\hline
\end{tabular}

The annual trends are printed in bold types. The most sensitive seasonal trends are presented in red, while the trends of the least sensitive seasons are in green. Since the duration of the mid-century cooling and the recent warming periods depend on regions, the actual periods for each region is presented in the header line

Station ID numbers marked with an asteriks $\left(^{*}\right)$ are national ID numbers, as they lack in WMO ID numbers

century period of stagnating temperature change and for the last 30 to 40 years of prominent warming. The trend calculation was made for the annual means and for each season: spring (March-May; for the Southern Hemisphere September-November), summer (June-August), autumn (September-November) and winter (December-February). The main results are presented for each station of the 18 groups classified in 10 regions of the world as in Table 1.

\section{The main results: the altitude dependency of a climatic temperature}

\subsection{The Swiss Alps}

To aid the interpretation of Table 1 that contains the basic material, a detailed illustration is presented for the first three groups. The Swiss Alps is made up of two groups, Jungfraujoch and Säntis. The Jungfraujoch group in Berneroberland is made up of two stations with available data for the period from 1933 to 2011 for Jungfraujoch and from 1931 to 2011 for Interlaken. The data of these stations were rigorously checked for their homogeneity by the Federal Office of Meteorology and Climatology (Swiss National Meteorological Service). They are $18 \mathrm{~km}$ apart from each other in horizontal distance with about 3,000-m-altitude difference. Since the trend calculation should be made based on the same period, the common period of 1933 to 2011 has been chosen as the entire period. The trend of the annual means for the entire period is $0.14{ }^{\circ} \mathrm{C} /$ decade for Jungfraujoch at 3,580 ma.s.1. and $0.09{ }^{\circ} \mathrm{C} /$ decade for Interlaken at 577 ma.s.1. The trends for the mid-century period (1933-1970) are -0.13 and $-0.10{ }^{\circ} \mathrm{C} /$ decade for Jungfraujoch and Interlaken, respectively. For the modern warming phase (1970-2011), the trend is 0.43 and $0.36{ }^{\circ} \mathrm{C} /$ decade for Jungfraujoch and Interlaken, respectively. For all periods, the trend is stronger at the high altitude of Jungfraujoch, than at Interlaken for both warming and cooling phases. The season of the strongest trend is clustered in the colder season from autumn to spring, while summer contributed least for the trend.

The comparison of Säntis with the lower sites was done in two different ways. The first is the station to station comparison for Säntis (2,502 ma.s.1.) and St. Gallen (776 m) for the common period of 112 years from 1901 to 2011 , which yields a slightly larger rate of $0.16^{\circ} \mathrm{C} /$ decade for Säntis in comparison with $0.14{ }^{\circ} \mathrm{C} /$ decade for St. Gallen at the foot of the mountain. This difference however is not significant with $95 \%$ confidence limit. For the mid-century period from 1933 to 1970 , the rate is 0.11 and $0.08{ }^{\circ} \mathrm{C} /$ decade for Säntis and St. Gallen, respectively. During the last 40 years from 1971 to 2011, the rates are 0.47 and $0.29{ }^{\circ} \mathrm{C} /$ decade, for Säntis and St. Gallen, respectively. The differences of the trends for the latter two phases are significant. The second comparison is made between the mountain site of Säntis and the mean temperature of the three stations surrounding the mountain, St. Gallen, EbnatKappel and Vaduz. This comparison is made only for the period of the modern warming phase from 1971 to 2011, as the observation at Vaduz started only in 1971. For this modern warming period, the mean warming rate at the foot of the mountain is $0.32{ }^{\circ} \mathrm{C} /$ decade, and clearly below the rate at the mountain peak of $0.47{ }^{\circ} \mathrm{C} /$ decade. The season that contributes most to this trend is spring. The faster rate of the temperature increase at the high-altitude site implicates the long-term decrease in lapse rate. The course of the seasonal temperature difference, however, is not the same as the seasonal trend of each station. The temperature difference between the two sites decreases mainly in summer $(0.05 \mathrm{C} /$ decade $)$ and autumn $(0.02 \mathrm{C} /$ decade $)$, while in winter and spring the temperature difference between the two sites has remained virtually unchanged during the last 40 years. 


\subsection{The Austrian Alps}

In Austria, one of the best conditions exists to evaluate the difference in temperature change between high altitude and the low-level plains in the climatic time scale. Namely Sonnblick Observatory (3,105 ma.s.1.), one of the oldest high mountain observatories, is located only $10 \mathrm{~km}$ in horizontal distance from Badgastein $(1,100 \mathrm{~m})$ with more than 2,000 m altitude difference. The observation at Badgastein started in 1853,33 years before the Sonnblick Observatory. The homogeneity of the time series for these stations allows the use of the data before 1901 . When the entire 125-year temperature observations are compared, the trends in annual means are 0.14 and $0.13{ }^{\circ} \mathrm{C} /$ decade, for Sonnblick and Badgastein, respectively. The difference is at $95 \%$ confidence level statistically not significant. Since the period of the last 125 years contains significant fluctuations, the periods with common trends were identified and the trend was computed for the individual phases. They are the first 63 years of the warming phase from 1887 to 1950 , followed by a cooling period from 1950 to 1980 and the last 30 years of strong warming. The trends for each period are larger at Sonnblick in comparison with Badgastein. Especially for the modern warming period of the last 30 years, the trends are 0.30 and $0.24{ }^{\circ} \mathrm{C} /$ decade for Sonnblick and Badgastein, respectively. This difference is significant at $95 \%$ confidence level. The stronger trend of warming at high altitude is also present in this case. Seasonally looking the clearest signal of the warming occurs in spring (0.60 and $0.43{ }^{\circ} \mathrm{C} /$ decade for Sonnblick and Badgastein, respectively) and summer $\left(0.46\right.$ and $0.39^{\circ} \mathrm{C} /$ decade for Sonnblick and Badgastein, respectively) and the weakest signal is seen in autumn.

\subsection{Pakistan and India}

There are at least two pairs of meteorological stations with adequate altitude differences, which have kept relatively long and continuous observation records in the high mountain regions of India and Pakistan. They are Srinagar (1,583 ma.s.1.) and Peshawar (359 m) in Kashmir, and Mukteshwar $(2,311 \mathrm{~m})$ and New Delhi $(216 \mathrm{~m})$ in the PreHimalayas. The main attributes for the four stations are presented in Table 1. Trends are calculated for three periods, for the longest period of the available temperature record of 1949-2010, for the first 30 years of slow changes from 1949 to 1980 and for the recent rapid warming period of 30 years from 1980 to 2010 . In all periods, the sites at higher altitudes showed larger rates of temperature rise in terms of annual means. The trends for the entire 60 years are 0.20 and $0.13{ }^{\circ} \mathrm{C} /$ decade for the higher and lower sites in Kashmir and 0.11 and $0.04{ }^{\circ} \mathrm{C} /$ decade for the Pre-Himalayas. For the first 30 years, the trends are $0.16^{\circ} \mathrm{C} /$ decade (higher site) and $0.10{ }^{\circ} \mathrm{C} /$ decade (lower site) for Kashmir, and $0.10{ }^{\circ} \mathrm{C} /$ decade (higher site) and $0.02{ }^{\circ} \mathrm{C} /$ decade (lower site) for the Pre-Himalayas. During the recent 30 years, the trends are $0.32{ }^{\circ} \mathrm{C} /$ decade (higher site) and $0.28^{\circ} \mathrm{C} /$ decade (lower site) in Kashmir, and $0.48{ }^{\circ} \mathrm{C} /$ decade (higher site) and $0.16{ }^{\circ} \mathrm{C} /$ decade (lower site) in the Pre-Himalayas. These differences are all significant. This region shows one of the clearest trends of the altitude amplification in the world. Seasonal means showed the steepest temperature rise in winter and spring at high-altitude sites, while at lower altitudes seasonal dependency is less obvious and the warming rate is very weak at all stations. Shrestha et al. (1999) examined the trend of daily maximum temperature based on the 25 years data from 1971 to 1994 for 49 sites in Nepal, ranging in altitude from 72 to 3,505 ma.s.l. to find the maximum warming at high altitudes.

\subsection{Mongolia}

A pair of high- and low-altitude stations in the continental climatic zone in the middle of the Eurasian Continent is Arvailkheer (1,813 ma.s.l.) at the eastern end of the Hangayn Nuruu Mountains and Choibalsan $(747 \mathrm{~m})$ near the country's lowest elevation in Mongolia. Based on the 70 years of records from 1940 to 2010 as parallel observations were made at both sites, the trend at Arvaikheer is $0.31{ }^{\circ} \mathrm{C} /$ decade, while it is $0.26{ }^{\circ} \mathrm{C} /$ decade at Choibalsan. During the mid-century of 30 years from 1940 to 1970 , the trend is mostly negative with a statistically insignificant difference. The temperature trend of the last 40 years shows rates of warming of 0.55 and $0.37^{\circ} \mathrm{C} /$ decade for Arvaikheer and Choibalsan, respectively. The warming rate of $0.55^{\circ} \mathrm{C} /$ decade at Arvailkheer for the last 40 years is the fastest temperature increase obtained in the present study presented in Table 1. Therefore, here, also a steeper temperature rise was witnessed at a high-altitude site.

\subsection{China}

In the Tienshan Mountains off the northern fringe of Taklimakan Desert, there is a high-altitude station, Daxigou (3,539 ma.s.1.) with more than 50 years of continuous observations in the high alpine tundra. Another station Hami is located $500 \mathrm{~km}$ east of Daxigou at an elevation of $739 \mathrm{~m}$. Although there are at least two longlasting stations between them, Houxia $(2130 \mathrm{~m})$ and Urmuqi $(935 \mathrm{~m})$, they are considered unsuitable for the long-term trend analysis because of the frequent station relocations and rapid development of settlements near the stations. Daxigou shows a considerably large warming trend in comparison to Hami, both for the entire period $\left(0.24{ }^{\circ} \mathrm{C} /\right.$ decade for Daxigou and $0.09{ }^{\circ} \mathrm{C} /$ decade for Hami) and for the recent 35 years $\left(0.32{ }^{\circ} \mathrm{C} /\right.$ decade for Daxigou and $0.05{ }^{\circ} \mathrm{C} /$ decade for Hami). The recent 
warming period in this area ended in 2005 , as the following years did not show a warming trend. During the mid-century decade from 1959 to 1970, the low-lying Hami showed a faster trend of cooling. Ten years however may be too short a period to evaluate a trend.

In other mountainous regions of China, there are at least two localities with a high cluster of stations that are separated with large altitude differences. They are the areas around Jiuquan in the Qilianshan Mountain Range and the north-eastern corner of Tibet around Toutouhe. In the Qilianshan region, the trend is clearly correlated with altitude for all three periods.

The region of Toutouhe shows a slightly different situation. In this region, the altitudes and the temperature trends are correlated for the range from Hanzhong (509 m.a.s.1.) up to the second highest site of Shiquanhe $(4,279 \mathrm{~m})$. The highest site of Toutouhe $(4,535 \mathrm{~m})$ however shows small trends in all phases. In view of the close distances of Toutouhe to other high-altitude stations in this region that do not share the trend, the uniqueness of the Toutouhe station must be due to an unknown strong local condition, or the lack of data homogeneity that the author could not investigate. The strongest trends in China are observed in winter. Liu and Chen (2000) examined 40 years of temperature from 97 stations in Tibet above 2,000 ma.s.l., and reported the larger trends at higher locations. Winter trends are the strongest.

\subsection{Japan}

Japan is a mountainous country and has many stations in high altitudes, which are accompanied by other stations on surrounding low lands. A meteorological observatory was established at the top of the nation's highest mountain, Fujisan in the summer of 1932, with the annual statistics starting in 1933. At the Fujisan Observatory (3,775 ma.s.1.), the temperature fluctuated greatly, although the mean trend was an increase. There was a warming period from 1930s to 1960 , which was followed by 25 years of cooling. The recent fast warming started in 1985, but a new cooling phase set in after 2005. The diurnal range of air temperature however increased throughout the last 80 years, whereby the increase in the daily maximum temperature was stronger than that of the daily minimum. The trend of the annual mean temperature at the Fujisan Observatory for the entire period is about the same as that of the mean temperature at the low altitude of Honshu, the main island, which is calculated based on the observations made at three reference stations (Fushiki $12 \mathrm{~m}$, Sakai $2 \mathrm{~m}$ and Hamada $19 \mathrm{~m}$ ). At Fujisan, the warming rate was $0.35{ }^{\circ} \mathrm{C} /$ decade during the recent 20 years from 1985 to 2005 . The comparison with the nearby lower sites, Kawaguchiko $\left(860 \mathrm{~m}, 0.51{ }^{\circ} \mathrm{C} /\right.$ decade) and Shizuoka $\left(14 \mathrm{~m}, 0.36{ }^{\circ} \mathrm{C} /\right.$ decade $)$ indicates that the fastest warming was observed at Kawaguchiko at an intermediate altitude and not at the highest altitude. The season that contributed most to the trend of the last 70 years was winter and spring, while summer was the trend-making season during the recent 30 years.

There are two groups of stations which can be studied for much shorter periods. These auxiliary sites are not listed in Table 1. A group of seven stations around Ibukiyama $(1,376 \mathrm{~m})$ in the Chubu Mountain Region, west of Fujisan, provides another opportunity of comparison for the semicontinental climatic region. The shorter period is the result of the termination of the observatory at the top of Ibukiyama in 2001. The comparison for the current warming phase from 1970 to 2000 shows a steady trend increase from the lowaltitude site of Hikone $\left(87 \mathrm{~m}, 0.62{ }^{\circ} \mathrm{C} /\right.$ decade) to Ibukiyama $\left(1,376 \mathrm{~m}, 1.11^{\circ} \mathrm{C} / \mathrm{decade}\right)$. The warming rate of the Ibukiyama Station is the largest rate observed at Japanese stations for this period. The temperature trends at the other five stations located between Hikone and Ibukiyama are $0.63{ }^{\circ} \mathrm{C} /$ decade for Minamishinano $(407 \mathrm{~m}), 0.73^{\circ} \mathrm{C} /$ decade for Iida $(516 \mathrm{~m}), 0.70^{\circ} \mathrm{C} /$ decade for Takayama $(560 \mathrm{~m}), 0.68^{\circ} \mathrm{C} /$ decade for Matsumoto $(610 \mathrm{~m})$ and $0.80^{\circ} \mathrm{C} /$ decade at the Suwa Observatory $(760 \mathrm{~m})$. Therefore, in the Chubu Mountain region, the temperature trends are strongly amplified with altitude.

On Kyushu Island in southwestern Japan there is a good coverage of observation around Asozan (highest peak, 1,592 ma.s.1.), an active volcano. The climate in this region is strongly maritime. From the observatory near the summit, a profile of the observational sites can be traced to the north. Along the profile, one sees the following warming rate for the period from 1985 to 2010: Asozan Observatory $(1142 \mathrm{~m})$ with $0.28^{\circ} \mathrm{C} /$ decade, Aso-Otohime $(497 \mathrm{~m})$ with $0.42{ }^{\circ} \mathrm{C} /$ decade and Hita $(83 \mathrm{~m})$ with $0.35{ }^{\circ} \mathrm{C} /$ decade. In this area, the largest temperature increase was observed at an intermediate altitude, similar to the Fujisan region.

\subsection{The Andes}

The region in and around the Andes offers a unique opportunity to investigate the trend in temperature change. Firstly, this is about the only area in the Southern Hemisphere with climatic observations at high altitudes. Secondly, the northsouth orientation of the mountain range allows sampling of the data from high latitudes to the equator. Thirdly, the effect of the altitude can be studied on the continental (east) as well as on the maritime (west) side of high mountains. The availability of homogenous time series in South America is limited. In the high-altitude areas there are no long homogenous records capturing the mid-century warm spell. Therefore, the study period in this section consists of only two phases, one leading to the end of the temperature stagnation between 1970 and 1985 and the other sampling the modern warming phase continuing to present. 
The region around Bariloche Aer ( 840 ma.s.1.) in the mid-latitude Andes shows the largest trend near the crest of the range and a quick decrease of the trend on the west slope towards Puerto Montt $(85 \mathrm{~m})$ on the Pacific coast in all phases. In fact, the trend on the Pacific coast is insignificant, except during the mid-century phase of 1963-1970. The most contributing season for the trend is the summer.

In the arid region of Atacama Desert from La Quiaca $(3,459 \mathrm{~m})$ down to Antofagasta $(135 \mathrm{~m})$ on the Pacific Coast, the trend decreases drastically as the altitude decreases in all periods. The trend is strongly influenced by spring temperatures. This strong altitude dependency is due to the small warming trend on the Pacific coastal region.

In the tropical Andes from the ridge region down to the Amazonas, the general tendency is also a larger trend at higher altitudes, except at the highest region. Slightly lower, Cuzco $(3,249 \mathrm{~m})$ shows a larger trend in comparison to the higher site at La Paz $(4,038 \mathrm{~m})$. A peculiar aspect of the temperature change in the tropical Andes is the temperature decrease in recent decades. During the last 25 years from 1985 to 2010 , most sites in the region experienced cooling with the fastest cooling at the highest site, La Paz.

Just north of the Equator in the region of Cordillera Oriental and Cordillera Central of Colombia, there are three stations suited for the present study: Bogota (2,548 ma.s.l.), Calipuerto $(964 \mathrm{~m})$ and Villavicencio $(431 \mathrm{~m})$. These stations are located east of the Andes but not in the Amazon Basin and are influenced strongly by the Caribbean Sea. The last 50 years from 1961 to 2010 shows a systematic increase of the trend with altitude. The same tendency applies also for the first 20 years from 1961 to 1980 . After 1980, however, the strongest warming is observed at Villavicencio, the lowest site, and the weakest warming appears at the highest station.

Vuille et al. (2003) analysed the temperature data of the tropical Andes for the latitude range between $1^{\circ} \mathrm{N}$ and $23^{\circ} \mathrm{S}$ and reported a trend of $0.15^{\circ} \mathrm{C} /$ decade for the period 1950 1994. The highest elevations reported a trend of approximately $0.05-0.20{ }^{\circ} \mathrm{C} /$ decade, with a slightly decreasing trend above 3,500 ma.s.l. These are similar to results found in the present study, although the temporal coverages of the study periods are different. Earlier, Vuille and Bradley (2000) reported a major warming on the coast and a decreasing trend with altitude. This conclusion contradicts the present analysis that shows an extremely small warming trend towards lower altitudes for all phases before and after 1970 .

\subsection{North American Cordillera}

In North America, groups of stations with large altitude differences were located in the North American Cordillera on the west coast and in the Appalachians near the east coast. The lower middle latitude group centred around Fly (1,909 ma.s.1.) on Egan Ridge in the U.S.A. is made up of the stations between Rocky Mountains and Sierra Nevada. For evaluating the altitude dependency, an additional station at a low altitude had to be selected inevitably from the Pacific side. Stockton was chosen at the foot of Sierra Nevada, which is well shielded from the Pacific effect by the Coastal Range. In this group, also a clear altitude dependency of the temperature trend is seen in all periods as summarized in Table 1. The season contributing to the trend of the annual temperature is the spring.

The other two groups were selected near the latitude of $50^{\circ} \mathrm{N}$, each from the Great Plains and the Pacific sides. On the profile from Banff (1,384 m) to Gleichen (905 ma.s.1.) in Canada, there is a systematic increase in trend for all periods as the altitude increases, except for the highest site, Banff. Banff and La Paz are the only two sites that showed a trend smaller than $0.1^{\circ} \mathrm{C} /$ decade among all high-altitude stations studied in this work. Since the temperature course for Banff during the twentieth century is so peculiar compared with other stations, the status of homogeneity of this station should be investigated in the future. The group of stations around Glacier National Park Mt. Fidelity/Fernie also shows the largest trend at the highest site for the entire observation period. During the earlier period from 1914 to 1970, Revelstoke, one of the two lower sites showed the largest trend. For the recent 35 years from 1970 to 2005 , there seems to be no altitude dependency in the trend. Seidel and Free (2003) obtained the largest trend at lower altitudes in the Rockies for the period 1979-2000. The stronger trends in the highlatitude Cordillera sites are seen in winter.

\subsection{The Appalachians}

Near the northern end of the Appalachians there is a pair of stations with long meteorological records in State of New Hampshire. Mount Washington at 1,910 ma.s.l. has records from 1937 to the present. Only $4 \mathrm{~km}$ from the Mount Washington Observatory, there is another station, Pinkham Notch at 613 ma.s.l. with observations from 1948 to present. The annual mean temperature for the two sites for the entire period of 60 years shows a larger warming trend at Mount Washington. Both sites experienced a cooling phase until mid-1960s, which turned into warming at the end of 1970s. During this cooling phase, the rate of cooling was larger at the lower station of Pinkham, and the trend-setting season was winter. During the recent 40 years of warming, the rate of temperature increase was larger at Mount Washington, with the strongest influence in autumn. The mean trend of strong warming at Mount Washington is also indicated by the decreasing temperature difference between the mountain and the low-land sites.

Summing up the analyses of the 18 groups of stations in 10 regions, there is a general tendency that the amplitude of climate change is larger at high altitudes in comparison with 
low lands. For the entire periods of the observation, 12 groups out of 18 showed a larger range of temperature change at high altitude. During the mid-century of stagnating temperature, 11 of 18 groups showed larger trends at higher sites. During the last 30 to 40 years, 12 out of 18 groups showed a larger warming rate at or near the summit of mountains, while four groups showed the largest warming trend at an intermediate altitude. The remaining two groups showed the fastest warming at the lowest site in the group. The areas that showed a larger trend at lower altitudes tend to be located in the region of maritime climate. The steepest warming trend was witnessed in the colder seasons of winter and spring rather than in the warmer seasons of summer and autumn. For the entire periods of the analyses, $67 \%$ of the stations showed the largest trend in winter and spring, while at the remaining $33 \%$ stations, the largest trend happened in summer and autumn. During the mid-century period, $64 \%$ of the stations had the maximum trend in winter and spring. During the current warming period, $72 \%$ of stations showed the fastest warming in winter and spring. Therefore, there is a tendency that high altitude and lower temperature tend to amplify the range or amplitude of temperature changes in a climatic time scale.

\section{Consideration on the altitude effect on climatic temperature change}

Cold regions are often cited as the geographic region where a larger climatic temperature change happens. The reasons attributed for this tendency are (1) cryosphere/temperature feedback and (2) temperature amplification in an inversion layer. The cryosphere/temperature feedback certainly makes a contribution also in the case of high-altitude sites. This is responsible for a larger trend in colder seasons. The second cause through an inversion brings about the larger convergence (negative divergence) of vertical sensible heat flux, amplifying the temperature change within a thin lowest atmospheric layer. In high mountain regions, however, an inversion is difficult to maintain, as cooled air drains to a lower altitude. This process certainly contributes to the amplification of the temperature variation at lower altitudes at the foot of the mountain, in a basin or on a plain. Therefore, in some groups discussed above, those stations at lower altitudes showing the largest temperature change, such as Villavicencio in Colombia and Revelstoke, British Columbia in Canada may have a stronger inversion effect making the larger amplitude of temperature change.

There are at least two more reasons why a high-altitude site creates larger amplitude or trend in temperature change. Both processes are based on the energy balance at the surface of the earth. (3) The third reason for the highaltitude amplification is a direct consequence of the energy balance at the surface and in the atmosphere. The mean state of the surface energy balance for the earth's surface can be written in the following manner:

$$
\begin{aligned}
& S(1-a)+L \downarrow+L E+H=\sigma T^{4} \\
& 175(1-0.15)+340-85-20=385 \mathrm{Wm}^{-2}
\end{aligned}
$$

where $S$ is global solar radiation, a is the mean surface albedo, $L \downarrow$ is long-wave incoming radiation, $L E$ is latent heat of evaporation, $H$ is sensible heat flux and $\sigma T^{4}$ is the surface emission. Presently, known best estimates of the global mean energy balance terms are presented below the equation (Ohmura 2006). This global mean state of the surface energy balance suggests that $80 \%$, the majority of the energy concentration at the surface, is transferred into the atmosphere through evaporation and less than $20 \%$ is transferred as enthalpy, which heats up the lower troposphere. The release of the majority of the surface heat production happens upon condensation in the middle troposphere. Newell et al. (1972) estimated the core of the latent heat release at $6 \mathrm{~km}$ above the sea level in the equatorial-tropical region and 3 to $4 \mathrm{~km}$ in the midlatitudes. Since the release of latent heat is much more powerful than the other heat sources in the atmosphere, the altitudes at which most condensation occurs can be considered as the altitude where the temperature trend reaches maximum. Since most of the causes of known climate changes are the change in radiation, it is probably natural that the result of climate changes is felt as the temperature variation at higher elevations. If the atmosphere is chronically moist as in many maritime regions, the condensation level tends to be lower. In such cases, the maximum temperature change may happen well below the highest stations in the region. This tendency was observed through the present analysis.

(4) The forth process causing the high-altitude temperature change is the natural consequence of the mathematical shape of the Stefan-Boltzmann equation, with which a surface reaches an equilibrium under given energy exchanges. Let the surface energy exchange and the effect of the flux variation on temperature change be expressed in the following manner:

$$
\begin{aligned}
& \sum_{i} F_{i}=\sigma T^{4}, \\
& 4 \sigma T^{3} \frac{d T}{d x_{j}}=\frac{\sum_{i} d F_{i}}{d x_{j}}, \\
& \frac{d T}{d x_{j}}=\frac{1}{4 \sigma T^{3}} \frac{\sum_{i} d F_{i}}{d x_{j}},
\end{aligned}
$$

where

$F_{i}$ is an energy flux

$T$ is temperature 
$\sigma \quad$ is Stefan-Boltzmann constant

$x_{j}$ is energy flux, or any climatic elements that can affect fluxes

Suppose a change in $x_{j}$ causes changes in energy fluxes exactly in the same manner in warmer and colder climates, so that $\sum_{i} d F_{i} / d x_{j}$ is the same for both climates, but $\mathrm{T}$ is different. For the same energy flux changes $\sum_{i} d F_{i} / d x_{j}$, the temperature sensitivity $d T / d x_{j}$ at $0{ }^{\circ} \mathrm{C}$ is $30 \%$ larger than at $25^{\circ} \mathrm{C}$, as a result of $T^{3}$ in the denominator (Ohmura 1984). This effect amplifies the temperature sensitivity of the energy balance change under lower temperature. All these processes contribute to cause a larger temperature variation in polar and high-altitude climate.

\section{Conclusion}

Based on the analysis of 50 to 125 years of time series of annual mean temperature at 56 stations in 18 groups selected from 10 mountainous regions of the world, the Alps, Kashmir, the Himalayas, Tibet, the Tienshans, the Qilianshans, the Japanese Archipelago, the Andes, the North American Cordillera and the Appalachians, $65 \%$ of the groups showed the largest trend of temperature change at the highest locations, $20 \%$ at an intermediate altitude between the summit and the foot of mountains, and the remaining $15 \%$ at the lowest altitude. The annual trend was most effectively influenced by the trends in colder seasons. The altitude is only one of many factors that influence the trend or amplitude of climate changes. The present analysis indicates, however, that the altitude is no doubt an important factor for causing a larger and faster temperature changes at high altitudes in many mountain regions. This tendency must be taken into account in high-altitude ecology, glaciology and permafrost research, when temperature data are available only at stations in lower altitudes. The present study shows the global importance of the observations at high altitudes. Especially for detecting and monitoring climate changes, high-altitude locations offer climatically sensitive sites, which are free from direct urban and industrial effects.

Acknowledgments The author wishes to thank Drs. Thomas Konzelmann and Ludwig Z'graggen of the Swiss Federal Office of Meteorology and Climatology, Zurich; Dr. Ingeborg Auer of Zentralanstalt für Meteorologie und Geodynamik (ZAMG), Vienna; Prof. Zhongqin Li of Cold and Arid Regions Environmental and Engineering Research Institute, Chinese Academy of Sciences, Lanzhou, and Mountain Washington Observatory, New Hampshire for helping the author obtain climatological data. The author is also indebted for valuable comments provided by Drs. Reinhard Böhm, Ernest Rudel and Wolfgang Schöner of Zentralanstalt für Meteorologie und Geodynamik (ZAMG), Vienna.

\section{References}

Auer I, Böhm R, Jurkovic A, Lipa W, Orlik A, Potzmann R, Schöner W, Ungersböck M, Matulla C, Briffa K, Jones P, Efthyadis D, Brunetti M, Nanni T, Maugeri M, Mercalli L, Mestre O, Moisselin J-M, Begert M, Müller-Westermeier G, Kveton V, Bochnicek O, Stastny P, Lapin M, Szalai S, Szentimrey T, Cegnar T, Dolinar M, Gajic-Capka M, Zaninovic K, Majstorovic Z, Nieplova E (2007) HISTALP-historical instrumental climatological surface time series of the Greater Alpine Regions. Int J Climatol 27:17-46

Barry RG (1992) Mountain weather and climate. Routledge, London, $402 \mathrm{pp}$

Beniston M, Diaz HF, Bradley RS (1997) Climatic change at high elevation sites: an overview. Clim Chang 36:233-251

Böhm R, Auer I, Schöner W, Ganekind M, Gruber C, Jurkovic A, Orlik A, Ungersböck M (2009) Eine neue Website mit instrumentellen Qualitätsklimadaten für den Grossraum Alpen zurück bis 1760 . Bemessung, Risikoanalyse und Vorhersage, Wiener Mitteilungen, Bd. 216: Hochwässer, pp 7-20

Diaz HF, Bradley RS (1997) Temperature variations during the last century at high elevation sites. Clim Chang 36:253-279

Jones PD, Wigley TML (1990) Global warming trends. Sci Am 263:84-91

Lanzante, J.R., Peterson, T.C., Wentz, F.J., and Vinnikov, K.Y. (2006) Chapter 3. What do observations indicate about the changes of temperatures in the atmosphere and at the surface since the advent of measuring temperature vertically? In: Karl, T.R., Hassol, S.J., Miller, C.D., and Murray, W.L. (eds.) Temperature trend in the lower atmosphere-step for understanding and reconciling differences. Synthesis and Assessment Product 1.1, pp. 47-70.

Liu X, Chen B (2000) Climatic warming in the Tibetan Plateau during recent decades. Int J Climatol 20:1729-1942

Messerli B, Ives JD (eds) (1997) Mountain of the world: a global priority. Parthenon, New York, 495 pp

MeteoSwiss (2010) Originale und homogene Reihen im VergleichTemperaturentwicklung an 12 Standorten des MeteoSchweizMessnetzes mit langjährigen Messreihen ab 1964. Mitteilung Dezember 2010. Zurich, Bundesamt für Meteorologie u. Klimatologie, $5 \mathrm{pp}$

Newell RE, Kidson JW, Vincent DG, Boer GJ (1972) The general circulation of the tropical atmosphere and the interactions with extratropical latitudes, vol 1. MIT Press, Cambridge, 258 pages

Ohmura A (1984) On the cause of "Fram" type seasonal change in diurnal amplitude of air temperature in polar regions. J Climatol 4:325-338

Ohmura A (2006) New radiation and energy balance of the world and its variability. In: Fischer H, Sohn B (eds) IRS 2004: current problems in atmospheric radiation, pp. 327-330.

Pepin N (2000) Twentieth-century change in the climate record for the Front Range, Colorado, U.S.A. Arct Antarct Alp Res $32: 135-146$

Pepin N, Seidel DJ (2005) A global comparison of surface and free-air temperatures at high elevations. Jour Geophys Res Do3104. doi:10.1029/2004JD005047

Peterson TC, Vose RS (1997) An overview of the Global Historical Climatology Network Temperature Database. Bull Am Meteorol Soc 78:2837-2849

Seidel D, Free M (2003) Comparison of lower-tropospheric temperature climatologies and trends at low and high elevation radiodonde sites. Clim Chang 59:53-74

Shrestha AB, Wake CP, Mayewski PA, Dibb JE (1999) Maximum temperature trends in the Himalaya and its vicinity: an analysis based on temperature records from Nepal for the period 1971-1994. J Climate 12:2775-2787 
Sterin AM, Khan VM, Rubinshtein K (2008) Upper-air temperature trends: current problems and some recent results. In: Brönnimann et al. (eds) Climate variability and extremes during the past 100 years. Advances in Global Change Research 33:85-101

Trenberth KE, Jones PD, Ambenje P, Bojariu R, Easterling D, Klein Tank A, Parker D, Rahimzadeh F, Renwick JA, Rusticucci M, Soden B, Zhai P (2007) Observations: surface and atmospheric climate change. In: Solomon S, Qin D, Manning M, Chen Z, Marquis M, Averyt KB, Tignor M, Miller HL (eds) Climate change 2007: the physical science basis. Contribution of Working Group I to the Fourth Assessment Report of the Intergovernmental Panel on Climate Change. Cambridge University Press, Cambridge

Vuille M, Bradley RS (2000) Mean annual temperature trends and their vertical structure in the tropical Andes. Geophys Res Lett 27:3885-3888

Vuille M, Bradley RS, Werner M, Keimig F (2003) 20th century climate change in the tropical andes: observations and model results. Clim Chang 59:75-99 